\title{
Unknown Primary Tumor pNX TNM
}

\section{Finding v8}

National Cancer Institute

\section{Source}

National Cancer Institute. Unknown Primary Tumor pNX TNM Finding v8. NCI Thesaurus.

Code C132666.

Unknown primary tumor in which the regional lymph nodes cannot be assessed. (from AJCC 8th Ed.) 